\title{
a experiência de pensar conceitos e o filosofar na infância na perspectiva de
}

\section{matthew lipman}

\author{
sandra dos santos alves ${ }^{1}$ \\ universidade estadual de londrina, brasil \\ orcid id: https:/ / orcid.org/0000-0002-2909-8385 \\ darcísio natal muraro ${ }^{2}$ \\ universidade estadual de londrina, brasil \\ orcid id: https:/ / orcid.org/0000-0002-5413-8385
}

resumo

Esta pesquisa busca compreender a relação entre a filosofia e a formação de conceitos na infância na perspectiva de Matthew Lipman. Como pesquisa própria da área de filosofia da educação, colocamos como problemática a ser analisada a seguinte questão: como a filosofia pode contribuir no processo de formação de conceitos na infância segundo Lipman? O desenvolvimento desta problemática foi organizada em cinco etapas. Uma primeira visa compreender e aprofundar a concepção de Filosofia para Crianças de Lipman, especialmente a ideia de habilidades de pensamento e diálogo filosófico na Comunidade de Investigação; a segunda etapa consistiu no planejamento da prática filosófica com as crianças na escola, em uma turma com 32 alunos do $3^{\circ}$ ano do Ensino Fundamental I de uma escola pública da cidade de Londrina/PR, no período de um semestre; a terceira foi realização da experiência em sala de aula com os alunos e a professora a partir das etapas anteriores; a quarta etapa foi a avaliação da prática e o planejamento das aulas seguintes após cada encontro; e a quinta etapa ocupou-se com o registro, análise e sistematização do observado. Com o objetivo investigar a contribuição da filosofia no processo de formação de conceitos na infância segundo Lipman, uma parte da metodologia da pesquisa foi de caráter qualitativo, analisando os conceitos de filosofia, pensar e Comunidade de Investigação deste filósofo. Para isso, foram consultadas suas obras principais e de seus comentadores. Foram empregados também os procedimentos da pesquisa-ação por meio da realização de práticas com alunos do Ensino Fundamental I, a fim de realizar uma experiência das concepções analisadas. Como resultado da pesquisa é possível destacar o papel fundamental da Filosofia para Crianças de Lipman para a formação de conceitos, pois, mediante as práticas filosóficas as crianças se mostraram mais reflexivas na abordagem de conceitos que no seu cotidiano poderiam passar desapercebidos. O trabalho de questionamento e diálogo em Comunidade de Investigação permitiu evidenciar a dificuldade de conceituar no início do trabalho, o progresso ao longo da abordagem dos mesmos e a necessidade de buscar respostas mais aprofundadas. Com isso, pode-se destacar que as aulas de filosofia contribuíram para tais avanços, e que sem elas as habilidades continuariam estagnadas. Este estudo vem se somar ao movimento filosóficoeducacional de ensino de filosofia desde a infância como imprescindível para a formação de sujeitos mais razoáveis, e o mais importante, com habilidades que facilitarão sua vida intra e extraescolar.

palavras-chave: educação; filosofia para crianças; lipman; formação de conceitos.

\footnotetext{
1 E-mail: sandra.dsalves@uel.br

2 E-mail: murarodnm@gmail.com
} 
a experiência de pensar conceitos e o filosofar na infância na perspectiva de matthew lipman

\section{la experiencia de pensar conceptos y filosofar en la infancia según la perspectiva de matthew lipman}

resumen

Esta investigación busca comprender la relación entre la filosofía y la formación de conceptos en la infancia desde la perspectiva de Matthew Lipman. Como pesquisa propia en el área de filosofía de la educación, planteamos la siguiente pregunta como un problema a analizar: ¿cómo puede contribuir la filosofía al proceso de formación de conceptos en la infancia según Lipman? El desarrollo de este problema se organizó en cinco etapas. El primero tuvo como objetivo comprender y profundizar la concepción de la Filosofía para Niños de Lipman, especialmente la idea de las habilidades de pensamiento y el diálogo filosófico en la Comunidad de Investigación; la segunda etapa consistió en planear la práctica filosófica con niños en la escuela, en una clase con 32 estudiantes del tercer año de primaria en una escuela pública en la ciudad de Londrina / PR, en el período de un semestre; el tercero fue llevar a cabo la experiencia en el aula con los alumnos y la profesora mediante las etapas anteriores; el cuarto paso fue la evaluación de la práctica y la planificación de las siguientes aulas después de cada reunión; y la quinta etapa se ocupó del registro, análisis y sistematización de lo observado. Para investigar la contribución de la filosofía al proceso de formación de conceptos en la infancia según Lipman, una parte de la metodología de investigación fué cualitativa, analizando los conceptos de filosofía, pensamiento y la Comunidad de Investigación de este filósofo. Para ello, se consultaron sus principales obras y las de sus comentaristas. Fueron utilizados también los procedimientos de investigación de acción participativa a través de la práctica con estudiantes de la Escuela Primaria I, para llevar a cabo una experiencia de los conceptos analizados. Como resultado de la investigación, es posible resaltar el papel fundamental de la Filosofía para Niños de Lipman en la formación de conceptos, porque, a través de las prácticas filosóficas, los niños fueron más reflexivos al abordar conceptos que en su vida diaria podrían pasar despistadamente. El trabajo de preguntas y diálogo en la Comunidad de Investigación permitió destacar la dificultad de conceptualizar al comienzo del trabajo, el progreso a lo largo de su enfoque y la necesidad de buscar respuestas más profundas. Con eso, se puede resaltar que las clases de filosofía contribuyeron a tales avances y que sin ellos las habilidades permanecerían estancadas. Este estudio se suma al movimiento filosóficoeducativo de la enseñanza de la filosofía desde la infancia como esencial para la formación de personas más razonables, y lo más importante, con habilidades que facilitarán su vida dentro y fuera de la escuela.

palabras clave: educación; filosofía para niños; lipman; formación de conceptos.

\section{the experience of thinking concepts and philosophizing in childhood from the perspective of matthew lipman}

abstract

This research seeks to understand the relationship between philosophy and the formation of concepts in childhood from the perspective of Matthew Lipman. As our own research in the area of philosophy of education, we pose the following question as a problem to be analyzed: how can philosophy contribute to the concept formation process in childhood according to Lipman? The development of this problem was organized in five stages. A first seeks to understand and deepen Lipman's conception of Philosophy for Children, especially the idea of thinking skills and philosophical dialogue in the research community; the second stage consisted of planning philosophical practice with the children at school, in a class with 32 students from the 3rd year of elementary school in a public school in the 
city of Londrina / PR, in the period of one semester; the third was to carry out the classroom experience with the students and the teacher from the previous stages; the fourth step was the evaluation of the practice and the planning of the following classes after each meeting; and the fifth stage was concerned with the registration, analysis and systematization of the observed. In order to investigate the contribution of philosophy to the concept formation process in childhood, according to Lipman, part of the research methodology was qualitative, analyzing the concepts of philosophy, thinking and the research community of this philosopher. For this, his main works and those of his commentators were consulted. Action research procedures were also employed through the practice of students from Elementary School I, in order to carry out an experience of the analyzed concepts. As a result of the research, it is possible to highlight the fundamental role of Lipman's Philosophy for Children in the formation of concepts, because, through philosophical practices, the children were more reflective in approaching concepts that in their daily lives could go unnoticed. The work of questioning and dialogue in the research community made it possible to highlight the difficulty of conceptualizing at the beginning of the work, the progress along their approach and the need to seek more in-depth answers. With that, it can be highlighted that the Philosophy classes contributed to such advances and that without them the skills would remain stagnant. This study is added to the philosophical educational movement of teaching philosophy from childhood, which is considered essential for the formation of more reasonable subjects, and most importantly, with the acquisition of skills that will facilitate life in and out of school.

keywords: education; philosophy for children; lipman; concept formation. 
a experiência de pensar conceitos e o filosofar na infância na perspectiva de matthew lipman

a experiência de pensar conceitos e o filosofar na infância na perspectiva de matthew lipman

\section{introdução}

O presente texto busca compreender a relação entre a filosofia e a formação de conceitos na infância na perspectiva de Matthew Lipman ${ }^{3}$. A análise aborda a filosofia da infância, concepção original de Lipman, que propugna uma educação voltada para a busca da excelência do pensar por meio do desenvolvimento das habilidades do conceituar. Esta análise engloba o ambiente filosófico-pedagógico da Comunidade de Investigação lastreada pelo diálogo filosófico como matriz impulsionadora desta prática educacional. Por fim, foi estabelecido um diálogo dos conceitos analisados com uma experiência realizada em uma escola da rede pública da cidade de Londrina, localizada na região norte do estado do Paraná, Brasil.

O que motivou esta pesquisa foi a inquietação com o modelo de educação atual, que prepondera na escola brasileira praticamente desde sua origem, e que tem caráter tradicional ${ }^{4}$, termo este usado para se referir à prática de transmissão

\footnotetext{
${ }^{3}$ O Prof. Dr. Matthew Lipman, filósofo e educador norte-americano, criou uma teoria filosóficopedagógica denominada Filosofia para Crianças no final da década de 60. O pensar filosófico constituiu o novo eixo orientador da educação para este pensador. Ele desenvolveu um paradigma de educação centrado no pensar reflexivo contraposto ao paradigma da educação tradicional que prioriza a transmissão de conteúdo. (cf. Lipman, 1995) Essa mudança radical na educação a partir da filosofia tinha por meta superar a crise que tomava conta da educação e da sociedade de sua época. 4 Aqui nos referimos à crítica de Lipman (1995, p, 28-29) à educação tradicional que ele denomina paradigma padrão da prática tradicional. Em contraste, Lipman elabora o paradigma reflexivo da prática do filosofar "O fazer filosofia exige conversação, diálogo e comunidade, que não são compatíveis com o que se requer na sala de aula tradicional. A filosofia impõe que a classe se converta numa comunidade de investigação, onde estudantes e professores possam conversar como pessoas e como membros da mesma comunidade; onde possam ler juntos, apossar-se de ideias conjuntamente, construir sobre as ideias dos outros; onde possam pensar independentemente, procurar razões para seus pontos de vista, explorar suas pressuposições; e possam trazer para suas vidas uma nova percepção de o que é descobrir, inventar, interpretar e criticar." (Lipman, 1990, p. 61). Conforme Madaloz, 2018, p. 38: "Ao contrário da pedagogia tradicional, caracterizada pela mera transmissão de informações, a comunidade de investigação, oriunda do pragmatismo, é uma prática que permite a construção do conhecimento em sala de aula." Para aprofundar este debate acerca da educação tradicional indicamos: Herbart (2003) que formulou os princípios da educação tradicional. Alguns críticos desta concepção: Dewey (1979a, 1979b, 1976); Claparède (1958); Eby (1978), e Durkheim (1995) ver especialmente neste autor a crítica ao modelo dos Jesuítas. Para aprofundar a discussão sobre a educação de caráter tradicional em termos nacionais indicamos as seguintes referências Franca (1951); Teixeira (1969, 1971, 2000, 2009); Freire (1989, 1980, 1998) e Magoga;Muraro (2020) Em parte, a crítica ao ensino tradicional é reforçada pela análise de Saviani (1991, p. 54, negrito nosso) que afirma: "Esse ensino tradicional que ainda predomina hoje nas escolas se constituiu após a revolução industrial e se implantou nos chamados sistemas nacionais de ensino, configurando amplas redes oficiais, criadas a partir de meados do século passado, no momento em que, consolidado o poder burguês, aciona-se a escola redentora da humanidade, universal, gratuita e
} 
compulsória de conteúdos no ensino escolar. Para cumprir essa tarefa ela sobreleva o aspecto mnemônico e minora a reflexividade. A afirmação se baseia na própria experiência de formação, nas práticas observadas nos estágios obrigatórios no curso de Pedagogia e no experimento deste trabalho. Deste diagnóstico surgiu a necessidade de estudar, como contraponto, o que uma uma proposta de educação que se propõe ser filosófica e democrática pode proporcionar às crianças, especialmente no que se refere à cultura do pensar excelente e dos conceitos centrais da experiência. A escolha da abordagem da conceituação deve-se ao fato desta se caracterizar como uma das principais tarefas da filosofia enquanto pensar crítico e criativo. Além disso, como a filosofia implica em pensar sobre seus próprios processos de pensar, este pensar sobre a conceituação o aprimorou sob a forma de habilidade do pensar. Outros aspectos incentivadores deste estudo foram: o interesse pela filosofia que se caracteriza como um encantamento pelas perguntas, a busca de excelência do pensar da metodologia filosófica do aprender pensando e dialogando, o pioneirismo de Matthew Lipman na concepção de Filosofia para Crianças (FpC), e a curiosidade pelo processo filosófico-pedagógico de formação de conceitos.

Os aspectos do trabalho apresentados anteriormente o caracterizam como uma pesquisa própria da área de filosofia da educação. Neste sentido a problemática que buscamos analisar tem esta formulação: como a filosofia pode contribuir no processo de formação de conceitos na infância segundo Lipman? Para desenvolver esta problemática adotamos a metodologia bibliográfica e qualitativa que permite proceder à compreensão da tecitura conceitual desenvolvida pelo autor acerca da conceituação na infância. O trabalho bibliográfico e conceitual foi feito a

\footnotetext{
obrigatória como um instrumento de consolidação da ordem democrática." Desta forma, nossa compreensão está amparada por densa análise da educação tradicional. Afirmamos que a educação tradicional prepondera, isto é, ela é predominante na educação brasileira. A afirmação não permite inferir que ela seja única e exclusiva. A experiência desenvolvida por Anísio Teixeira no Centro integrado de Educação Popular Carneiro Ribeiro, em Salvador / Bahia (Escola Parque) merece ser citado e estudado como contraponto à educação tradicional. Entretanto, as proposições de Teixeira e da escola nova não chegaram a se consolidar como prática educativa com amplitude nacional e foram duramente combatidos pelas tendências conservadores. Outras práticas realizadas por Paulo Freire ou nele referenciadas e em Lipman também merecem ser citadas e estudadas como contraste à educação tradicional. Por fim, reforçamos a importância de análise crítica ao modelo de educação tradicional, de caráter conservador, militar e oposto às humanidades, que vem sendo implantado pelas políticas educacionais do atual governo brasileiro.
} 
a experiência de pensar conceitos e o filosofar na infância na perspectiva de matthew lipman

partir da análise das obras de Lipman e de seus comentadores como Ann Margaret Sharp, Laurance J. Splitter, Marie France Daniel e Walter Kohan, bem como da fonte primeira de Lipman que é a filosofia da educação de John Dewey.

Em virtude disso, organização da pesquisa foi pensada em cinco etapas. Uma primeira para compreender e aprofundar a concepção de Filosofia para Crianças, especialmente ideia de habilidades de pensamento e diálogo filosófico na Comunidade de Investigação; a segunda para o planejamento da prática filosófica na escola; a terceira foi realização da experiência em sala de aula com os alunos e a professora a partir das etapas anteriores; a quarta, a qual foi realizada de forma dialógica, para a avaliação da prática e o planejamento das aulas seguintes; e a última para registro, análise e sistematização do observado.

\section{filosofia e filosofia para crianças}

Como filósofo e professor, Lipman entende que a filosofia é um campo de conhecimento fundamental para a sociedade, decorrendo daí sua importância para a educação. Ele considera que a filosofia tem como objeto de estudo os conceitos, e, por isso, apurou esta habilidade essencial para o ser humano entender a vida e condução da ação no mundo. Sem o trabalho filosófico de conceituar a experiência não conseguimos compreender-nos como sujeitos sociais, nem o que está para além do imediato, aparente e histórico na existência. Portanto, sem a filosofia não poderíamos compartilhar do mundo humano, pois ele não teria se construído como resultado do trabalho dos seres humanos ao longo da história. Os conceitos são parte estruturante das nossas experiências como seres sociais. Diz o autor: "A filosofia, portanto, é muito benéfica para as pessoas que procuram formular conceitos $^{5}$ que possam efetivamente representar aspectos de sua experiência de vida." (Lipman, 1994, p. 52). Neste sentido, a filosofia se constitui num campo de conhecimento basilar à sociedade e à educação. Como a sociedade é constituída

\footnotetext{
5 "Os pensamentos que se transformam em conceitos servirão para trabalhar com outros pensamentos e ideias advindos de novas experiências, formando o perene movimento do pensar. (Madaloz, 2018, p. 12). “Talvez seja essa uma das possíveis contribuições da filosofia para o mundo humano: pensá-lo, dando inteligibilidade à experiência, compreendendo-a através de conceitos que sirvam de ferramentas para que possamos nos posicionar e agir na concretude do mundo." (Filho; Velasco, 2019, p. 93)
} 
pelos conceitos que lhe dão identidade cultural, a educação é a mediação de apropriação sempre renovada destes conceitos pelas pessoas para continuidade da sociedade. Por conseguinte, no caso da educação, os conceitos são elementares à constituição dos estudos de qualquer área do conhecimento e à consequente inserção social. Para Lipman, a tarefa da filosofia é trabalhar sobre o conceito: análise reflexiva de crítica, criatividade e cuidado. Para esse autor, o trabalho da filosofia como disciplina voltada para pensar os conceitos é feito levando "[...] em consideração formas alternativas de agir, criar e falar." (Lipman, 1994, p. 143). Neste sentido, a filosofia rompe com as formas rotineiras de agir ao buscar alternativas conceituais para pensar e orientar este agir reflexivo, para imaginar um mundo mais humano e justo e para uma comunicação social mais compreensiva. Nesta perspectiva, a atividade filosófica é valorizada pelo trabalho sobre conceitos, que dá lastro para diversas áreas de investigação produzirem conhecimentos, além de proporcionar a discussão crítica sobre os valores, conforme entende Lipman:

A filosofia contém, além de muitas outras coisas, um núcleo de conceitos. Estes conceitos são incorporados e ilustrados em todas as áreas humanas, mas é na filosofia que são analisados, discutidos, interpretados e esclarecidos. Muitos destes conceitos representam valores humanos profundamente importantes, como a verdade, $\mathrm{o}$ significado e a comunidade. (...) Sem a filosofia, há uma tendência para que os comportamentos que estes conceitos representam permaneçam inarticulados e sem expressão. A filosofia na escola primária fornece um espaço que possibilita às crianças refletirem sobre seus valores, assim como sobre suas ações. Graças a estas reflexões, as crianças podem começar a perceber maneiras de rejeitar aqueles valores que não estão à altura dos seus padrões e de guardarem aqueles que estão. A filosofia oferece um espaço no qual os valores podem ser submetidos à crítica. Esta é, talvez, a principal razão para sua exclusão, até agora, da sala de aula da escola primária, e uma razão fundamental para que seja, agora, finalmente incluída. (Lipman, 1995, p. 240-241).

O autor deixa explícito o trabalho perscrutador da filosofia em relação aos conceitos: inquirir, examinhar, analisar, discutir, interpretar, criticar, esclarecer e criar significados alternativos. Pela reflexão filosófica estes conceitos se tornam valores humanos que todos deveriam ter acesso por procedimentos críticos. $\mathrm{O}$ trabalho filosófico em torno dos conceitos se justifica porque eles têm implicações diretas sobre o entendimento de cada um sobre o mundo, de si mesmo, como ser humano, e, principalmente, da formação da consciência (Vygotsky, 1988; Leontiev, 
a experiência de pensar conceitos e o filosofar na infância na perspectiva de matthew lipman

1978). Portanto, a filosofia impacta tanto sobre o caráter das pessoas quanto no modo social de organizar a vida da comunidade.

A análise filosófica busca compreender a gênese da formação dos conceitos, sua relação com o contexto do agir experiencial guiado por significações criadas historicamente e sempre sujeitas a definições alternativas. Neste processo, o pensamento trabalha com habilidades que permitem criar significações a partir de semelhanças e diferenças, do esclarecimento de ambiguidades, da detecção de pressupostos, do inferir sobre as relações de causa e consequência, meios e fins, parte e todo, e do considerar as implicações para a vida social. Esta prática, segundo Daniel (2000), possibilita o desenvolvimento do pensamento conceitual, pois ela “[...] se exercita na definição dos conceitos, em estabelecer distinções e em criar relações, o que levará eventualmente a habilidades de pensamento cada vez mais elevadas." (Daniel, 2000, p. 116).

Para Lipman (1990)6 , a filosofia é fundamental para a humanidade e em específico para a educação porque ela é a fonte de ideias que lastreia as disciplinas e que suportam seu progresso investigativo. Ela elabora os aspectos genéricos que circunscreve toda atividade do pensamento que ocorre na aprendizagem em qualquer disciplina:

A filosofia estimula o pensamento nas disciplinas pois assume a responsabilidade de ensinar os aspectos genéricos do pensamento que ocorrem em qualquer disciplina e porque é um modelo daquilo que significa para uma disciplina refletir sobre e ser crítica da sua propria metodologia. (Lipman, 1995, p. 381)

Podemos observar que a atividade da filosofia é coeva ao desenvolvimento das disciplinas. Não é um saber do passado, mas atualiza-se permantemente toda vez que se faz crítica em qualquer disciplina que, por sua vez, poderá trazer novos problemas para a própria filosofia. Sendo assim, ela é um campo que se preocupa em pensar o pensamento quanto a sua rigorosidade, alcances e limites conceituais. Conforme Lipman $(1990)^{7}$, o trabalho da filosofia no processo de pensar os conceitos

\footnotetext{
${ }^{6}$ Assim como Madaloz (2018)

${ }^{7}$ E "Segundo Sharp (1999), esses conceitos fazem parte da espinha dorsal da filosofia e são comuns às experiências de todos ou da maioria que pensa. Podem ser centrais na maneira como se vê e se dá sentido à experiência, e contestáveis ou problemáticos, pois nem sempre podem ser definidos com clareza ou finalidade. Por isso, é fundamental ajudar as crianças a terem clareza desses conceitos e o
} 
e pensar o próprio pensar conceitual adquire centralidade no campo da educação: ela preocupa-se com o esclarecimento dos conceitos por meio de procedimentos como criticar, descobrir pressupostos, definir com rigor, analisar consequências, processos que subsidiam o trabalho criativo do conceituar. $\mathrm{O}$ acúmulo deste trabalho cooperativo ao longo da história lhe permite oferecer um conjunto de conceitos elaborados, destacando-se sua atividade como fonte fértil de novas ideias como busca de alternativas diante de perplexidades ou situações problemáticas.

A filosofia é um campo de conhecimento que valoriza o processo de pensar os conceitos tendo em vista a criação de significados que orientam a atividade humana. Nas palavras de Lipman (1990, p. 13): “A filosofia oferece um forum no qual as crianças ${ }^{8}$ podem descobrir, por si mesmas, a relevância, para suas vidas, dos ideais que norteiam a vida de todas as pessoas." Por muito tempo, ela foi reservada às pessoas adultas consideradas capazes de racionar de acordo com as exigências do pensamento filosófico elaborado. Para a tradição da filosofia, somente as pessoas adultas seriam capazes de raciocinar com tamanha profundidade (Daniel, 2000, p.11). Lipman (1995) rompe com este pressuposto da tradição filosófica, considerando que a atividade da filosofia de criação de conceitos que consitituem o ser humano é um direito de todas as pessoas, independente de idade, uma vez que este processo interfere na própria identidade da pessoa. Assim, a filosofia é uma necessidade básica para significar a experiência por meio da qual vamos nos constinuindo como seres pensantes, agentes e viventes numa cultura, numa comunidade de crenças compartilhadas ao mesmo tempo que este processo transforma a própria comunidade. Por sua vez, significar a experiência envolve a

\footnotetext{
que eles significam na experiência; também que eles são diferentemente interpretados, e como essas diferentes interpretações são importantes para viver a própria vida." (Madaloz, 2018, p. 34)

8 Para Lipman as crianças também possuem direito de filosofar, pois conseguem organizar seus pensamentos: "Outra coisa surpreendente é o fato de relacionarem os pensamentos entre si, tanto de uma forma lógica como de uma forma gramatical. Evidentemente as crianças possuem essas disposições de organizar seus pensamentos e suas falas de uma forma gramatical e lógica. (Lipman, 2014, p. 40). Além disso, sobre sua concepção de Filosofia, baseada em Sócrates também afirma "Para ele não se tratava de uma aquisição nem de uma profissão, mas de um modo de vida. O que Sócrates nos exemplifica não é uma filosofia conhecida nem aplicada, mas praticada. Este nos desafia a reconhecer que como obra, como forma de vida, a filosofia é algo a que qualquer um de nós pode dedicar-se (Lipman, 1990, p. 28). Lipman assim servia-se da filosofia grega quanto à promoção do diálogo em sala de aula, ao qual se dá pela via da investigação, e pela busca pelas novas respostas aos questionamentos humanos, pondo à prova as verdades dadas na sociedade. (Segundo, 2017, p. 50)
} 
a experiência de pensar conceitos e o filosofar na infância na perspectiva de matthew lipman

capacidade de raciocinar que permite formular discursivamente os signifcados e poder usá-lo nas próximas experiências, bem como, comunicá-los socialmente. $\mathrm{O}$ autor ressalta a importância da filosofia para este processo: "A disciplina que mais se relaciona com o desenvolvimento da racionalidade através do raciocínio aperfeiçoado e da formação de conceitos" (Lipman, 1995, p. 46). Seguindo esta argumentação, o autor chama atenção para o início do processo de formação do raciocínio na infância.

$\mathrm{O}$ argumento do autor defende que a criança aprender a raciocinar nos primeiros estágios de seu desenvolvimento, isto é, no período inicial da aquisição da linguagem:

É nesta época que a criança aprende a raciocinar - apesar de não ser explicitamente ensinada a fazê-lo. A criança quando aprende a falar coloca sujeitos em frente de predicados; fornece objetos para verbos transitivos; infere que a negação da consequência de uma condicional implica na negação do antecedente; descreve; narra; explica e até funciona metacognitivamente, fazendo julgamentos quanto à verdade ou falsidade das afirmações. (Lipman, 1995, p. 47)

Para Lipman, a aprendizagem do raciocínio na aquisição da linguagem permite à criança a prática do filosofar pois ela poderá pensar melhor através da linguagem e estar sensível aos aspectos lógicos do discurso. Caso contrário, se tornam vítima de discursos prontos. O autor alerta para o impacto que este processo tem para a vida racional:

Se as habilidades sintáticas e lógicas foram corretamente aprendidas antes do jardim da infância, estas nos assistirão durante toda nossa vida, pois a reunião destas habilidades é a plataforma ou o fundamento sobre o qual nossas vidas enquanto criaturas racionais são construídas. (Lipman, 1995, p. 47)

Para o autor, a presença da disciplina de filosofia no currículo permite aos professores diagnosticar as deficiências de aquisição destas habilidades de raciocínio e criar oportunidades para a criança melhorar sua capacidade de pensar. Neste sentido, o autor está preocupado com a excelência do desempenho de todas as habilidades: "O que deve ser melhorado são todas a habilidades e a maneira de sincronizar ou orquestrar todas elas" (Lipman, 1995, p. 50). Desta forma, o autor contesta as práticas educacionais que visam o treino de habilidades estanques como se num passe de mágicas elas passassem a funcionar integradamente. Faz-se necessário ressaltar sua insistência: “A educação envolve mais que apenas o 
desenvolvimento de habilidades" (Lipman, 1995, p. 50). Uma educação centrada no atividade de treino de habilidades compromete a função social da própria educação. Isto porque, a nosso ver, as habilidades podem ser usadas, inclusive, para fins antisociais. Assim, por exemplo, a excelência no raciocínio pode ser usada para criar um discurso falacioso. Um caso muito ilustrativo do contexto social atual é o fenômeno das fakes news em que a racionalidade é usada para fins de obter vantagens políticas ludibriando o eleitor. Neste sentido, promove o discurso de ódio e a violência social nas mas diversas formas. Na perspectiva de Lipman, o adequado trabalho educacional de desenvolvimento de habilidades de pensamento necessita do aporte da disciplina humanística da filosofia comprometida com a reflexão e com a investigação preocupada com aspectos humanísticos como a ética, a política e a estética. Ressaltamos o posicionamento do autor:

A lição é que as habilidades do pensamento devem também ser ensinadas em um contexto de uma disciplina humanística para evitar que as habilidades sejam mal empregadas. A disciplina mais adequada, neste caso, seria aquela comprometida com o fomento da investigação humanística em relação a conceitos problemáticos, porém significativos. Consequentemente, é a disciplina de humanidades da filosofia e não somente as habilidades do raciocínio que devem ser ensinadas como uma parte integral dos currículos da escola primária e secundária. A filosofia representa para o ensino do pensamento o que a literatura representa para o ensino da leitura e da escrita. (Lipman, 1995, p. 51)

O trabalho educacional de aprimoramento das habilidades por meio da filosofia se deve à dimensão humanística desta que consiste em pensar os diversos aspectos implicados no uso das habilidade como o da lógica, da ética, da política, da estética, da metafísica. Para o autor, esta dimensão humanísta do pensar habilidoso evita o "mal emprego" na medida em que poderia minimizar estes aspectos da experiência.

Como professor de lógica no ensino superior, Lipman deparou-se com vários estudantes, que tinham filosofia em seus currículos, mas que não conseguiam pensar criticamente e manifestavam dificuldade de pensar reflexivamente. Ele elaborou o problema filosófico a partir de sua própria experiência como como professor: os estudantes da graduação chegavam nesta etapa com seu pensamento já formado e tão solidificado que quando se deparavam com questões e situações 
a experiência de pensar conceitos e o filosofar na infância na perspectiva de matthew lipman

em que deveriam pensar criticamente não o conseguiam fazer. A partir deste diagnóstico, ele, como professor de lógica, indagou-se: “Haveriam eles de raciocinar melhor em função de seus estudos de lógica? Não estariam seus hábitos linguísticos e psicológicos tão solidamente arraigados que todo tipo de método ou de ensino relativo ao raciocínio chegava um pouco tarde?" (Lipman apud Daniel, 2000, p. 1718). Tal fato, segundo ele, devia-se a uma formação tradicional centrada numa prática mnemônica de aprendizagem de conteúdos. $\mathrm{O}$ autor destaca que o paradigma padrão do ensino tradicional falha em seu pressuposto que relega o pensar a um segundo plano como subsidiário do acúmulo de pensamento, como se aquele fosse um ato mágico deste. Nesta perspectiva, como contraponto, destaca-se a contribuição da filosofia pela unidade de seu fazer: ela não somente pensa os pensamentos, mas pensa as condições de possibilidade destes.O questionamento crítico do autor também poderia ser estendido à educação básica: uma sociedade que não cultiva a reflexão filosófica, é pouco afeita ao diálogo e aceita passivamente as imposições da mídia, da religião, das forças políticas representadas na figura dos líderes, governantes, órgãos de controle social, bem como no poder das ideologias, e da própria escola está fadada ao fracasso porque não é autônoma na formulação de seus conceitos identitários. Segundo ele, a filosofia na educação desde a infância é fundamental, pois:

[...] os programas escolares atuais dão pouca importância à compreensão dos conceitos gerais, dos valores, das normas e dos critérios. [...] Se se quer que as crianças aprendam a pensar de forma crítica, criativa e autônoma, urge preencher essa lacuna. Nada me parece mais adequado que a filosofia para cumprir essa tarefa. (Lipman apud Daniel, 2000, p. 10-11).

Para Lipman, o trabalho da filosofia na educação consiste no aprimoramento do pensar crítico, criativo e autônomo. A autonomia no pensar representa a prática da liberdade da criança de criar os conceitos significativos a partir de sua experiência na troca comunicativa da comunidade. Dessa forma, a criança se liberta dos tutores que lhe dizem o deve pensar e fazer, de uma moral punitivista e da política de submissão. O desafio é garantir a perspectiva humanística da filosofia ao lidar com conceitos complexos e com o aperfeicoamento do pensar. Por isso, Lipman entende que o filosofar é uma atividade que se faz por meio do diálogo numa comunidade de pensantes: 
A filosofia é um disciplina que inclui a lógica e, portanto, se ocupa em introduzir os critérios de excelência no processo do pensar para que os estudantes possam caminhar do simples ato de pensar para o pensar bem. Ao mesmo tempo, a tradição filosófica desde o século VI a C. tem sempre lidado com um conjunto de conceitos considerados importantes para a vida humana ou relevantes para o conhecimento humano. Exemplos desses conceitos são: justiça, verdade, liberdade, bondade, beleza, mundo, identidade pessoal, personalidade, tempo, amizade, liberdade e comunidade. Sem conceitos como esses, funcionando como idéias reguladoras, teríamos muito mais dificuldade em dar sentido à nossa experiência. [...] É indispensável que as crianças adquiram esses conceitos se querem dar sentido aos aspectos sociais, estéticos e éticos de suas vidas. Existe uma idéia errônea de que as crianças não estão interessadas nas noções filosóficas e querem apenas divagar sobre trivialidades ou dominar as informações. (Lipman, 1994, p. 47-48).

Nesta perspectiva, considerando que a educação é um direito fundamental do ser humano, poderíamos dizer que o acesso à filosofia é um direito educacional fundamental: o de dar sentido à experiência. Além disso, ela pode dar suporte para as habilidades básicas do ensino como a fala, a leitura, a escrita e as operações matemáticas. Superam-se, assim, os argumentos dos legisladores que defender um currículo centrado nas habilidades mínimas de ler, escrever e contar e que colocam a filosofia como uma inimiga da educação das crianças e jovens. Exige também repensar a formação dos professores para que se apropriem desta sabedoria para sua prática pedagógica.

Lipman consubstanciou sua concepção de filosofia e educação numa proposta que chamou de Filosofia para Crianças (FpC). Este programa, diferentemente das propostas que focam um ensino de filosofia baseado na transmissão do pensamento filosófica numa perspectiva hitoricista, tem como preocupação fazer filosofia com a criança, isto é, uma prática que visa propiciar a investigação de conceitos problemáticos da experiência, ancorada em habilidades do pensar que permitem um olhar multifocal ${ }^{9}$ por meio do diálogo. Certamente as demais áreas de conhecimento corroboram o processo de desenvolver habilidades de pensamento, mas a filosofia o faz através do diálogo em torno dos conceitos

\footnotetext{
9 Favero; Centenaro; Kapczynski, 2019, p. 67. 
a experiência de pensar conceitos e o filosofar na infância na perspectiva de matthew lipman

humanísticos ${ }^{10}$, numa comunidade de prática de valores, estes também sob o crivo filosófico. Na perspectiva do autor, conceitos filosóficos e habilidades de pensamento tem generalidade mais ampla que as disciplinas, mas impactam no processo de aprendizagens:

[...] "fazer filosofia" consiste, por um lado, em refletir sobre conceitos, tais como a verdade, a justiça, a relação, o significado, que pertencem a uma ordem muito mais geral para serem estudados pelas outras disciplinas; por outro lado, é participar de discussões sobre os critérios e normas que envolvem esses conceitos. É essa concepção da prática filosófica que a Filosofia para Crianças privilegia. (Lipman apud Daniel, 2000, p. 10, aspas no original).

Segundo Lipman, sem o trabalho de reflexão sobre estes conceitos e o desenvolvimento das habilidades propiciadas pelo fazer filosófico que propicia a autonomia na criação dos significados, as crianças não poderão se tornar responsáveis pelas suas próprias atividades mentais e morais, e consequentemente pelas suas ações uma vez que não podem deliberar nem escolher. Desta forma, considerando indispensável o fazer filosófico na condução da experiência, Lipman entendeu que se faz necessária uma reforma na própria filosofia se se reconhece que seu cabedal de conceitos é condição para o desenvolvimento humanístico do pensamento $^{11}$. O experimento que o autor desencadeou por meio do projeto de Filosofia para Crianças, representa a possibilidade de tornar acessível a filosofia para as crianças, reconstruindo seus conceitos no diálogo investigativo como Platão fizera:

Para que se torne acessível aos jovens, seria necessário voltar-se contra a própria filosofia e reconstruí-la. Ora, o programa de Filosofia para Crianças é precisamente uma reconstrução da filosofia. [...] Com efeito, para muitos a Filosofia para Crianças ainda continua sendo algo estranho. Ainda é preciso, pois aumentar a credibilidade do programa. [...] O mesmo acontece com qualquer projeto educacional novo que causa perplexidade. (Daniel, 2000, p. 11).

Tal reforma foi necessária a fim de romper com um tradicionalismo histórico presente também na filosofia o qual sustenta que ela está ligada somente à abstração, teoria e ao ensino formal, somente possível para níveis mais elevados do

\footnotetext{
${ }^{10}$ Estes conceitos são importantes para a constituição do ser humano e da sociedade. Lipman (1990 / 1994) destaca os conceitos relativos aos campos de investigação filosófica como a ética, a política, a estética.

${ }^{11}$ Isto é, em sua integralidade.
} 
sistema de ensino, normalmente a graduação ${ }^{12}$ (Favero; Centenaro; Kapczynski, 2019, p. 65). Diante disso, de acordo com Daniel (2000) a maior qualidade do programa lipmaniano foi o ineditismo ${ }^{13}$. Em uma perspectiva consoante, Lipman, a fim de adaptar a filosofia clássica às crianças, criou uma coleção de novelas filosóficas que podem ser utilizadas, de acordo com sua classificação de faixa etária, da Educação Infantil ao Ensino Médio.

Apesar de iniciante, segundo Walter Kohan, em seu livro Filosofia para Crianças na prática escolar, o programa Filosofia Para Crianças é uma proposta em crescimento, isso certamente devido à sua perspectiva de construção coletiva e permanente. Ele rejeita dogmatismos e preconceitos, por conseguinte, segundo Kohan (1998, p.11), “[...] pela prática os educadores estão determinando o significado educacional deste programa, bem como estão revelando novos significados filosóficos e educacionais possíveis para esta ideia". Percebe-se que é uma proposta aberta aos diálogos do dia a dia dos docentes e ao seu contexto. Diferentemente das tentativas históricas anteriores, a proposta lipmaniana rejeita sua aplicação como um manual que deve ser estritamente seguido, mas compreende que cada lugar, cada contexto tem sua especificidade, bem como cada professor sua capacidade de recriar conforme seu contexto e valores. Desde sua concepção, o programa teve como alvo a instituição escolar visando mudanças no sistema de ensino, já que sua problemática central foi criada em razão das defasagens de uma formação mais reflexiva, crítica e criativa praticado na época em que foi concebido e que vem sendo implementado até os dias de hoje. Todas as adaptações sugeridas para a apresentação de uma filosofia contextualizada às crianças foi devido a um

\footnotetext{
${ }_{12}$ Outras obras que também falam sobre o tradicionalismo filosófico: Daniel (2000); Gareth Matthews (2001) e Scheler (1986).

13 "Lipman fundamentou-se em filósofos antigos e contemporâneos por terem pensado os problemas da educação, sobretudo quando tratam da Filosofia para a formação integral da pessoa. Tais filósofos defendem a Filosofia como "exercício" substancial à vida de todo homem, o que oferece para Lipman uma base para que defenda sua presença e importância da discussão filosófica em sala de aula." (Brocanelli, 2010, p.29). Quando fala-se em formação integral fala-se em formação humanística, pois envolve os vários aspectos da vida do educando, sua relação com o mundo e sua subjetividade também. Quando se menciona a Filosofia como exercício refere-se ao fato de que ela está presente no cotidiano humano e que o mesmo a utiliza e exercita constantemente, conforme Chauí (2000). “De acordo com Matthew Lipman, 1990, o método socrático de filosofar não restringe ninguém, pois esta é uma filosofia praticada e vivida, portanto a filosofia não se tratava em formar filósofos, mas de uma forma de vida pensante [...]" (Segundo, 2017, p. 49)
} 
a experiência de pensar conceitos e o filosofar na infância na perspectiva de matthew lipman

entendimento diferente de infância pelo autor.

\section{a busca da excelência do pensar}

O pensamento, segundo Lipman, é uma capacidade humana que pode ser aperfeiçoada aproveitando-se da longa tradição filosófica de reflexão sobre o próprio pensar. Conforme sua perspectiva, é inegável que todas as pessoas pensam, mas não factível que todas as pessoas pensam bem. Diante disso, ele entende que existe o pensar bem, e que em contraposição a ele, há um pensar não excelente, como é o caso do pensar espontâneo. Lipman atribui à filosofia o esforço de buscar a excelência do pensar e à educação o cumprimento desta tarefa. Neste sentido, sua preocupação é também com a excelência na educação. Sua indagação é: “o que pode ser feito para tornar a educação mais crítica, mais criativa e mais avaliativa em relação aos seus próprios procedimentos? Eu recomendo, para começar acrescentar Filosofia aos currículos das escolas primárias e secundárias." (Lipman, 1995, p. 43). Ressaltamos que Lipman fala da filosofia conforme entendimento explicitado no início deste trabalho.

O pensamento espontâneo, encontrado mais frequentemente e conhecido como senso comum, consiste em um pensamento desleixado, caracterizado pela aceitação passiva dos fatos, sem questionamento, marcado pela realização de julgamentos rápidos e afirmações não justificadas. Em contrapartida, o pensar bem é aquele que está ciente de suas próprias suposições, implicações, razões e provas. É um tipo de pensamento fundamentado, capaz de identificar tendências, preconceitos e autoilusões. Logo, é um pensamento marcado pela reflexão, rigorosidade, aprofundamento, criticidade, criatividade, contextualização e autocorreção. Este é o pensar que habilita o trabalho sobre os conceitos.

O pensar, conforme o autor:

[...] é o processo de descobrir ou fazer associações e disjunções. O universo é feito de complexos (não há, evidentemente, realidades simples) como as moléculas, as cadeiras, as pessoas e as idéias, e estes complexos têm ligações com algumas coisas e não com outras. O termo genérico para associações e disjunções é relacionamentos. Considerando que o significado de um complexo encontra-se nos relacionamentos que este tem com outros complexos, cada relacionamento, quando descoberto ou inventado, é um significado, e grandes ordens ou sistemas de relacionamentos constituem 
grandes corpos de significados. (Lipman,1995, p.33)

O pensamento então é o processo de descobrir e/ou estabelecer relações entre as significações da experiência, sejam elas materiais ou imateriais. Pode-se dizer que tais significações são os conceitos. Logo, o pensar está estreitamente relacionado com a filosofia como capacidade de pensar os conceitos criando corpos de significados a partir da experiência. Consequentemente, ela não aceita conceitos vagos, razos ou mal fundamentados, mas se preocupa com a validade dos processos de raciocínio na produção do significado (Daniel, 2000, p. 173), assim como o pensamento excelente.

Conforme Lipman (1995, p.40), o pensar bem é gestado no contexto da Comunidade de Investigação, isto é um ambiente em que várias pessoas estão dispostas a investigar um determinado tema através do diálogo. Neste caso, é preciso que alguém com mais experiência investigativa medeie o processo e que os participantes sintam confiança para pensar com os outros, o que estabelece uma relação social de compartilhamento das ideias. Além disso, é imprescindível que tal processo seja amparado pelo pensar por meio das habilidades da crítica, da criatividade e do cuidado.

Para que um pensamento seja caracterizado ou avaliado como excelente é necessário que ele seja multidimensional, ou seja, composto pelos pensamentos crítico, criativo e cuidadoso. O pensamento crítico é um tipo de pensamento que envolve a compreensão global do significado e do contexto, ele abarca o questionamento, não como um ceticismo, mas como uma investigação a fim de chegar a uma compreensão coerente, fundamentada (Daniel, 2000). Ele faz uma análise daquilo com o que se depara, ou melhor, faz julgamentos; é guiado por critérios, quer dizer, requer consistência, relevância e precisão; é autocorretivo, dado que avalia os próprios procedimentos e métodos (Lipman, 1995). Um ponto a destacar é que "Não há pensamento crítico sem o mínimo de julgamento criativo" (Lipman, 1995, p. 39), pois é preciso criatividade para se realizar novas críticas; e também, uma abertura, compreensão e aceitação das novas elaborações.

O pensamento criativo é um tipo de pensamento que valoriza a concepção e não a réplica de uma informação obtida, isto é, a autenticidade (Daniel, 2000). Ele envolve habilidade, talento, imaginação, pois não se prende ao pré-estabelecido, é 
a experiência de pensar conceitos e o filosofar na infância na perspectiva de matthew lipman

autotranscendente, pois tem como propósito a expansão de limites, e maiêutico, na geração de conhecimentos e produções novas. Possui como base o pensamento estético e não existe sem o mínimo de julgamento crítico (Lipman, 1995, p. 39), visto que, sem um mínimo de críticidade não consegue distinguir as produções próprias das outras; e superar o concebido até o momento.

A terceira dimensão do pensar multidimensional é a reflexão guiada pelo cuidado, como aspecto ético do pensar. Este pensamento não guia o sujeito para um ideal de racionalidade unicamente, mas para o que é razoável (Daniel, 2000). Ele é constituído pela curadoria, a preservação, a restauração, a empatia na participação imaginativa na experiência dos outros, e principalmente a ética, já que, preocupa-se com tudo o que for vivenviado como bom e certo de acordo com seus critérios base (Lipman, 1995). É um pensamento que envolve também um mínimo de criticidade e criatividade ao considerar o outro, mediante a imaginação, e também o embasamento de seus critérios.

O pensar excelente é um pensar que vai apurando as habilidades ${ }^{14}$ de reflexão. Elas são como ferramentas ou instrumentos do pensar. Alguns exemplos de habilidades são os atos de presumir, supor, comparar, inferir, contrastar ou julgar, para deduzir ou induzir, classificar, descrever, definir ou explicar (Lipman, 1995) entre muitas outras. Elas podem ser classificadas em mega-habilidades raciocínio, investigação, conceituação e tradução - aquelas que requerem um pensamento mais complexo, e habilidades básicas, aquelas que são importantes para os processos elementares. Ambas possuem o mesmo grau de importância e auxiliam-se mutuamente. A diferença entre elas está na sequência e coordenação que elas desempenham com outras habilidades:

O que é importante sobre a sequência e o estabelecimento de habilidades é, obviamente, que isto torna possível um enorme aumento da capacidade e eficiência. [...] um currículo eficaz ensinará aos alunos de que maneira as habilidades podem ser empregadas cumulativamente para que uma possa reforçar a outra.

\footnotetext{
${ }^{14}$ As quais “[...] são explicadas por Lipman como ações que visam criar condições para favorecer um pensar melhor" (Fernandes, 2018, p.198).

São consideradas "capacidades do pensar" (Vale, 2019, p. 39)

"[...] são entendidas como modos de ação para tratar de situações problema. Essas habilidades formam a estrutura fundamental do que se poderia chamar de competência cognitiva permitindo discriminar entre objetos, fatos ou estímulos, identificar e classificar conceitos, aplicar regras, levantar, construir e resolver problemas." (Zompero; Figueiredo; Laburu, 2017, p.4260)
} 
(Lipman, 1995, p.59).

Assim, percebe-se a importância das habilidades para a educação, além da relevância do trabalho e da organização das mesmas. Além desse aspecto é importante ressaltar que nossas habilidades não necessariamente aumentam e melhoram à medida que amadurecemos, tais implicações dependem se estas são desenvolvidas ou não.

Considerando que o foco deste artigo é a conceituação, focaremos a análise com mais profundamente neste tipo de habilidade, com base na obra O pensar na educação de Matthew Lipman.

As habilidades de formação de conceitos são aquelas que envolvem a organização de informações que recebemos em unidades ou grupos significativos, isto é, redes de relações formando corpos conceituais. Cada relação é uma unidade de significado e cada grupo representa uma teia de significados. Os conceitos são veículos do pensamento, ou seja, agrupamentos de sentidos semelhantes, e entidades mediante as quais o pensamento se realiza e que podem ser expressas através de palavras. A análise dos conceitos envolve o esclarecimento e a remoção de ambiguidades, o que para Lipman pode ser um trabalho muito árduo. É importante ressaltar que a formação de conceitos é a descoberta ou construção de significados dentro de uma determinada linguagem. Ela requer a organização de tais informações em grupos de relações, isto é, análise e esclarecimento para facilitar sua utilização na compreensão e no julgamento. A posse de conceitos é fundamental, pois é por meio da articulação deles que o pensar é realizado.

Para a formação de conceitos são necessárias as habilidades de explicação e decomposição e recomposição de palavras; busca de significados, como por exemplo em livros, dicionários, memória, etc.; a observância das características essenciais das coisas; e por último a definição, ou seja, possuir a capacidade de dizer o que algo é, e o que o torna inconfundível. Sem ter uma base conceitual refletida não é possível investigar, raciocinar, traduzir e principalmente viver significativamente.

É provável que crianças muito pequenas possuam todas as habilidades de forma elementar. Assim, o papel da escola é desenvolvê-las. A educação não é uma questão somente da aquisição de habilidades cognitivas, mas de como empregá-las; 
a experiência de pensar conceitos e o filosofar na infância na perspectiva de matthew lipman

também do fortalecimento e aperfeiçoamento das mesmas: “Em outras palavras, as crianças estão naturalmente inclinadas a adquirir habilidades cognitivas, do mesmo modo que adquirem naturalmente a linguagem, e a educação é necessária para fortalecer o processo." (Lipman, 1995, p. 65). Com isso, pode-se afirmar que o papel da educação seria o de trabalhar o pensamento excelente mediante a abordagem das habilidades cognitivas, porém, de acordo com Lipman e Ann Margareth Sharp (apud Daniel, 2000, p. 113) nosso sistema educacional atual, baseado nas concepções tradicionalistas ${ }^{15}$, não educa nesse sentido:

Ou ela age como a mamãe pássaro que põe pedaços de comida na boca dos filhotes oferecendo as crianças todas as respostas que elas precisam apenas memorizar, ou então ela faz o jogo do Avestruz, entendendo o pensamento lógico e razoável como uma faculdade que se desenvolve por si mesma e que portanto não necessita de nenhuma aprendizagem específica.

De acordo com a passagem, este tipo de educação ou dá as respostas diretamente para as crianças ou considera que o pensar bem é algo que se desenvolve automaticamente com a simples apresentação do conhecimento sistematizado e acumulado pela humanidade, ou seja, as disciplinas. Segundo Lipman (1995) ${ }^{16}$, o conteúdo das disciplinas não é o suficiente para ensinar o pensar excelente mas é necessário todo um trabalho mediante o filosofar na Comunidade de Investigação e na proposição de atividades de pensamento para que as crianças desenvolvam as habilidades de pensamento:

Os críticos [da educação americana] sempre reclamam que as crianças raciocinam muito pouco porque a leitura e a matemática são mal ensinadas. E as escolas reagem a isso de forma frenética, procurando novas maneiras de ensinar essas matérias de forma mais adequada. Raramente acontece de uma das partes considerar que, ainda que a leitura e a matemática sejam disciplinas úteis ao pensar bem, elas não bastam para criá-lo. O fato de que João soma, subtrai, multiplica, divide e é capaz de ler rapidamente um livro de Danny Dunn, não significa que ele consegue raciocinar. Tampouco significa que, fazendo isso, ele desenvolva habilidades de pensamento eficaz ou de julgamento autônomo. É preciso algo mais (Lipman, 1976, p.18)

\footnotetext{
${ }^{15} \mathrm{~A}$ vida moderna é caracterizada pela fragmentação geral da experiência, que também se reflete no parcelamento do dia a dia escolar. O modelo educacional que se estabeleceu baseia-se na transmissão de conhecimentos e informações do professor para os alunos e, diante disso, a necessidade de ser simplificado e esquematizado por especialistas. (Favero; Centenaro; Kapczynski, 2019, p. 66)

16 Assim como Lipman (2014, p. 33)
} 
Este algo mais a que o autor se refere corresponde a uma educação que valoriza a excelência do pensar em que seus profissionais se interessam em prover momentos de diálogo e situações em que as habilidades cognitivas sejam aprimoradas. Situações, por exemplo, em que os alunos sintam a necessidade de apresentar julgamentos com base em critérios e/ou valores, apresentem definições, realizem perguntas, analisem suas afirmações e as comparem com as dos outros, e, assim, tirem suas conclusões, entre outros aspectos. Com base no abordado nos tópicos anteriores, pode-se inferir que é inegável que a educação é fundamental para o desenvolvimento humano, porém não qualquer tipo de educação.

\section{a comunidade de investigação e o diálogo filosófico}

A Comunidade de Investigação consiste em um grupo de pessoas, neste caso, alunos e professores, empenhados conjuntamente a investigar um assunto que é problemático. Indispensavelmente, os assuntos investigados pertencem ao universo dos alunos, constituindo-se uma ferramenta chave para uma aprendizagem significativa:

Do mesmo modo que os cientistas empregam o método científico para a exploração de situações problemáticas, assim deveriam fazer os alunos caso quisessem aprender a pensar sozinhos. Ao contrário disto, pedimos a eles que estudem os resultados finais daquilo que o cientista descobriu; desprezamos o processo e fixamos nossa atenção sobre o produto. Quando os problemas não são explorados em primeiro lugar, nenhum interesse ou motivação é criado, e aquilo que continuamos chamando de educação é uma charada e um simulacro. Dewey não tinha a menor dúvida que o que deve acontecer dentro da sala de aula é que se pensasse - um pensamento independente, imaginativo e rico. $\mathrm{O}$ caminho por ele proposto - e neste ponto alguns dos seus seguidores o abandonaram - é de que o processo educativo na sala de aula deveria tomar como modelo o processo da investigação científica. (Lipman, 1995, p. 31).

Para a realização da Comunidade de Investigação alguns componentes são necessários. Um dos principais componentes é o diálogo ${ }^{17}$, ou seja, uma fala em que há a interação entre dois ou mais indivíduos e que tem como objetivo o desenvolvimento da compreensão e do julgamento adequados. Segundo Lipman

\footnotetext{
17 Tanto a investigação quanto o diálogo filosófico, na comunidade de investigação, capacitam os alunos a ampliar o leque das interconexões que proporcionam um entendimento mais amplo das coisas. (Favero; Centenaro; Kapczynski, 2019, p. 69)
} 
a experiência de pensar conceitos e o filosofar na infância na perspectiva de matthew lipman

(1995), ele é o princípio pelo qual o significado de algo é construído, é o lugar onde as relações se estabelecem e as aprendizagens se integram. Assim, é uma interação humana histórica, contextual e social que transcende o pessoal e busca a investigação de um problema comum. O diálogo é de suma importância, pois é mediante o mesmo que o homem aprende, isto é, se constitui:

[...] é um engano pensar que a criança se transforma em ser social pela aprendizagem, sem perceber que ela deve ser social para que possa aprender. Portanto, Mead percebe a importância de uma comunidade de investigação educativa, porque elas proporcionam uma discussão ativa da matéria de estudo. (Muraro, 2015, p. 37).

A aprendizagem então, conforme Mead (1910), se dá através das interações adquiridas na sociabilidade entre indivíduos. A socialização, interação mediada, é uma prerrogativa para aprendermos algo. Consequentemente, o diálogo não é conversa, pois possui um objetivo e uma intencionalidade. Conforme Lipman: “As conversações não são uniformemente contínuas; existem lacunas e hiatos por toda parte - falamos sem pensar e então voltamos atrás." (Lipman, 1995, p. 336). Tampouco é um discurso retórico, visto que seu objetivo principal não é o convencimento a todo custo, mas a busca de conceituação razoável podendo haver consenso ou mesmo dissenso em torno da argumentação. De forma distinta à retórica, o diálogo, objetiva o crescimento de seus participantes, mesmo se estes apresentam visões diversas. Logo:

O diálogo encontra-se, evidentemente entre estas duas extremidades, pois não é totalmente livre de propósitos, e pode muito bem compreender argumentos cujo objetivo seja o de persuadir. O diálogo, ao contrário da conversação, é uma forma de investigação, e como seguimos a investigação para onde ela conduzir, não podemos afirmar que nosso comportamento dialógico é não intencional. Nem tampouco aqueles que participam de um diálogo necessariamente deixam de elaborar argumentos a fim de convencerem os outros participantes da honestidade das suas convicções. (Lipman, 1995, p. 340).

O diálogo tem elementos da conversação, como a fala entre pessoas livres e iguais, a relação simétrica entre elas, comunicação entre as individualidades; também possui traços da retórica, como a colocação das opiniões, a fala organizada e a elaboração de argumentos para o embasamento das convicções. Porém, não se limita a estas práticas, seu objetivo principal é o crescimento e a elaboração conceitual de seus participantes. Logo, nem todas as comunidades chegam a uma 
conclusão, mas podem apresentar um produto de sua reflexão. O produto que resulta da investigação é qualquer mudança produzida desde o início das discussões e é inevitavelmente gerado no processo da discussão. Assim, a Comunidade de Investigação não é algo sem objetivos, mas um processo que tem sentido e direção, isto é, movimenta-se para onde o argumento conduz, logo, o verdadeiro diálogo segundo Lipman citando Buber ${ }^{18}$ :

[...] ocorre somente quando cada um dos participantes "realmente tem em mente o outro, os outros em sua existência presente específica e volta-se para estes com a intenção de estabelecer uma relação mútua estimulante entre si e eles." Em termos ideais, a relação entre professor e alunos possui esta qualidade de diálogo de comunicação direta. Ela é simultaneamente, uma comunidade que expõe tanto a aprendizagem quanto o respeito mútuo [...] (Lipman, 1995, p. 34, aspas do autor).

A Comunidade de Investigação, especialmente quando utiliza o diálogo, é o contexto social mais apropriado para a geração do pensamento complexo ou excelente, pois permite a operacionalização e implementação das definições do pensar crítico, criativo e ético, os quais compreendem o pensamento complexo tão necessários à prática democrática na educação:

A comunidade de investigação é a sementeira necessária para o cultivo da filosofia na escola primária, pois ela intermistura a preocupação crítica com a justiça e o impulso criativo em direção ao interesse e à atenção. Ela gera o respeito tanto pelos princípios quanto pelas pessoas, fornecendo, deste modo, um modelo de democracia como investigação. (Lipman, 1995, p. 367-368)

Outro ponto importante é que o diálogo e a Comunidade de Investigação possuem como base o questionamento. Este vem da curiosidade e perplexidade diante do mundo. A indagação, inquietação ou dúvida que geram investigação que proporciona o crescimento, o entendimento do mundo e de si mesmo. A investigação exige a racionalidade, ou seja, emprega habilidades e ferramentas lógicas na investigação do problemático. Devemos raciocinar a fim de podermos acompanhar o que está ocorrendo em seu interior de uma investigação. Tais aspectos são trabalhados gradualmente na comunidade, já que geralmente, os participantes iniciantes não possuem tais habilidades de forma desenvolvida. Por

${ }_{18}^{18}$ Martin Buber (1878-1965), filósofo, escritor e educador o qual valorizava o diálogo na educação e na vida. 
a experiência de pensar conceitos e o filosofar na infância na perspectiva de matthew lipman

conseguinte, o propósito da Comunidade de Investigação é o desenvolvimento da autonomia; no sentido em que os pensadores autônomos são aqueles que pensam por si mesmos na relação com os outros, e não repetem simplesmente o que outras pessoas dizem ou pensam. Por isso, a autonomia depende de uma prática social de pensar, falar e agir. Por isso, a comunidade de investigação tem potencial mais amplo para a prática educacional: não se restringe à avaliação de acúmulo de conhecimento, mas ao complexo processo do agir social.

A prática da Comunidade de Investigação possui normas de procedimento cuja natureza, na sua maior parte, é de ordem lógica. Para Lipman, a lógica é compreendida nas suas diferentes modalidades como a lógica formal, a lógica das boas razões, a lógica do agir racionalmente (Cf. Lipman, 1994). Como prática de pensar necessariamente ativa, a mesma é orientada pela qualidade gestáltica ${ }^{19}$ da situação única imediatamente experienciada que implica em tomar posicionamentos diferenciados, produzir julgamentos, utilizar critérios para a formulação de tais julgamentos, exploração dos significados, entre outros aspectos lógicos. Além disso, é uma forma de praticar aspectos éticos uma vez que necessita que seus membros tenham empatia, o respeito mútuo, saibam ouvir e falar em momentos adequados e de forma acolhedora, entendam que possuem direitos e deveres e que principalmente é preciso confiança.

Em consonância com Lipman (1995) e Daniel (2000), Araújo (2007) afirma que a Comunidade de Investigação constitui um fórum no qual permanentemente se discutem os problemas que avultam a realidade de seus participantes. Ao mesmo

\footnotetext{
${ }^{19}$ Concepção baseada no conceito de "Gestalt" a qual compreende que o todo ou conjunto não é simplesmente a soma ou combinação de elementos, mas uma unidade com ordem definível (Abbagnano, 2007, p. 470; 810). "As aplicações das descobertas da Gestalt na Educação são muito importantes por não utilizarem o exercício puramente mecânico no processo de aprendizagem. [...] a aprendizagem acontece através de um insight, que se constitui numa compreensão súbita para solução de problemas, até então sem resposta, sendo a aprendizagem uma reorganização do campo cognitivo que permite a compreensão de um problema e a sua solução." (PRADO, 2017, p. 12). O termo insight refere-se: “(...) à dinâmica experimentada nos campos emocional e de motivação não menos que à determinação experimentada em situações intelectuais". (KÖHLER, 1980, p.195). "A experiência passada, apesar de não conseguir resolver o problema, facilita a compreensão de uma nova situação. É objetivo central da Gestalt [...] possibilitar ao indivíduo o desenvolvimento completo das capacidades e de todo o seu potencial, segundo Burow e Scherpp (1981), (...) é apenas preciso que se criem as condições necessárias." (PRADO, 2017, p. 13). Segundo esta concepção, o presente é valorizado, pois é mediante o mesmo que as condições e os pensamentos atuais podem ser modificados. A totalidade é observada como complexa e dinâmica.
} 
tempo é um lugar de quebra de preconceitos e da abordagem da diversidade humana.

No ambiente da comunidade investigativa, não são somente os discentes que aprendem, mas também os docentes, pois é necessário que eles saibam como e quando intervir para que aconteça um bom diálogo. Conforme Lipman:

Conseguir com que os estudantes se envolvam num diálogo filosófico é uma arte. E como qualquer arte, um pouco de conhecimento é um pré-requisito - nesse caso, o professor deve saber quando intervir ou não numa discussão. Há ocasiões em que o melhor que se pode fazer para dirigir uma discussão filosófica é não dizer nada e deixar que as coisas aconteçam. De fato, a meta em direção à qual uma discussão filosófica deve se dirigir é uma situação em que haja uma máxima interação estudante-estudante, em contraste com o início de tal discussão, em que predomina a interação professor - estudante. (Lipman, 1994, p. 157).

A capacidade de guiar uma discussão investigativa, conforme o autor, é uma arte, pois depende de conhecimentos teórico-práticos os quais são adquiridos na formação, inicial e continuada do professor, além do dia a dia em sala. O desafio, citado nas entrelinhas, consiste na associação de tais conhecimentos a fim de alcançar uma práxis tanto na Comunidade de Investigação, mediante os ensaios de circunstâncias reais, quanto nas situações do cotidiano. A formação indicada por Lipman (1994) para os docentes que desejam trabalhar com filosofia na sala de aula é composta por três componentes fundamentais, a explicação, modelagem e experienciação, conforme:

Nenhuma explicação da arte de ensinar filosofia pode ser adequada para o professor que está se preparando para isso. Primeiro, é preciso admitir que os próprios filósofos nunca tiveram muita clareza sobre o que fazem quando ensinam filosofia. Portanto, faltanos uma compreensão ampla sobre em que uma explicação adequada pode se basear. Segundo, mesmo se tivéssemos tal explicação, seria insuficiente se o filósofo não modelasse de forma competente, unindo a uma experiência de professor, o que é envolver-se num diálogo filosófico. Esses três componentes explicação, modelagem e experiência - são indispensáveis na preparação dos professores para ensinar filosofia para os alunos de $1^{\circ}$ grau. (Lipman, 1994, p. 172-173).

A explicação consiste no conjunto de conhecimentos que o professor vai adquirindo em sua formação acadêmica, por meio do processo de transmissão, leituras e pesquisas. A modelagem é a experiência de aprendizagem realizada em 
a experiência de pensar conceitos e o filosofar na infância na perspectiva de matthew lipman

uma atividade compartilhada em Comunidade de Investigação com um professor mais experiente. O conteúdo compartilhado é primeiramente compreendido, adequado à realidade dos estudantes e às necessidades educativas. A experiência consiste na prática do professor iniciante com sua classe de alunos, procurando recriar a prática de modelagem com os conhecimentos adquiridos com o novo grupo. A presença destes três componentes é básica para o professor que pretende trabalhar com uma aprendizagem de forma reflexiva, lógica, coerente e ética.

Ademais, cabe ao docente também fazer com que a sala de aula, ou seja, o espaço em que se dão as discussões, seja um ambiente de confiança, agradável, onde as crianças ou seus participantes se sintam livres de forma física, emocional e intelectual. Somente assim poderão expressar-se livremente, sem preconceitos. Ao discutir os assuntos e abordar temas ou conceitos até então desconhecidos, as crianças poderão sentir uma profunda satisfação ao entender um assunto e começar a compreender o que era confuso (Lipman, 1994, p.172). É dessa forma que o diálogo filosófico procura lidar com o que é mais imprescindível na experiência humana, por isso, requer uma formação rica, principalmente em Filosofia para Crianças, pois sem tais conhecimentos a educação das crianças torna-se maçante e qualquer metodologia empregada não cumprirá seu fim. Além do mais, sem uma boa formação e experiências, o docente não conseguirá chegar a níveis mais filosóficos de diálogo que requeiram por exemplo a inferência, generalização, o apontamento de contradições, a identificação de pressuposições subjacentes, entre outros aspectos do pensamento conceitual. Por causa disso, é importante que o professor compreenda bem o programa para assim tentar concretizá-lo no seu dia a dia. É devido a isso, que Walter O. Kohan afirma que antes de filosofar "é preciso que o professor saiba "fazer acontecer" com os alunos a filosofia para crianças. [...] objetivando interesse e a aprendizagem do educando" (Kohan, 1998, p.16), num sentido de coordenação, mediação e não de autoritarismos. Para o fazer filosófico é preciso entender como a Comunidade de Investigação pode ser planejada, realizada e avaliada, a fim de obter-se uma educação reflexiva no dia a dia escolar e principalmente coragem para experienciar, com a compreensão de que terão ações 
adequadas, inadequadas e que tudo isso é um processo para a aprendizagem, do professor e de seus educandos.

a experiência de filosofar em sala de aula: transformação das crianças e da professora

O esforço deste trabalho não foi apenas de compreender as ideias centrais de Lipman acerca do trabalho com a filosofia na escola. Procuramos levar estas ideias ao campo empírico para poder analisar com mais propriedade sua importância na educação. A experiência em comunidade aconteceu em um colégio estadual de ensino fundamental na cidade de Londrina, Paraná. Este campo foi escolhido por ser um espaço da universidade dedicado à realização de pesquisas educacionais. Trata-se de um ambiente mais receptivo ao investigar acadêmico, por atender a comunidade próxima à universidade e formar parte da rede pública da cidade. Isso possibilitou um o contato com alunos e professores que não são expressamente da universidade e uma visão mais próxima da realidade educacional da cidade. $\mathrm{O}$ objetivo da mesma era a verificação da importância da filosofia na formação de conceitos na infância, utilizando como base a metodologia da Comunidade de Investigação e as demais concepções de Lipman já abordadas anteriormente.

Após a apresentação da proposta para o colégio, foi indicada a realização do projeto de pesquisa com a turma do $3^{\circ}$ ano $\mathrm{B}$, uma classe regular do Ensino Fundamental I com 32 alunos com idade de 8 e 9 anos. Os encontros aconteceram uma vez por semana, com duração de uma hora, no decorrer de um semestre. As atividades foram feitas no colégio, ou seja, na sala de aula, em espaços abertos, coletivos e sobretudo no Campus da UEL em salas disponíveis. Como requisito, foi solicitado o envio dos planejamentos semanais com um certo período de antecedência para a coordenadora pedagógica da escola, para análise e liberação.

No total foram feitos 14 encontros, sendo os dois primeiros destinados à apresentação de atividades introdutórias, devido à necessidade de inicialização dos alunos na Comunidade de Investigação, e os demais dedicados ao trabalho dos conceitos escolhidos pela turma. Todos eles seguiram a proposta de trabalho da Comunidade de Investigação, com uma metodologia que envolve cinco momentos 
a experiência de pensar conceitos e o filosofar na infância na perspectiva de matthew lipman

ou etapas: a ambientação, que faz contato com a experiência da criança; a leitura que promove o contato com uma experiência cultural sistematizada; a problematização em que se geram as perguntas investigativas; a discussão / investigação em que se dialoga sobre determinado problema conceitual e a produção de significados ou conceituação, momento em que elaboram e registram significados a partir do processo desenvolvido. (Cf. Muraro, 2015)

Ao todo foram trabalhados quatro conceitos principais: amizade, pessoa, história e criatividade. A cada prática eram levados: textos de diferentes gêneros, músicas e atividades diferenciadas como painéis e dinâmicas. Todos os conceitos foram escolhidos pelos discentes e trabalhados mediante Comunidade de Investigação.

Nos encontros iniciais as aulas tiveram por objetivo a apresentação do projeto aos alunos, ademais do que seria uma roda de discussão e uma Comunidade de Investigação, já que as crianças nunca tinham participado de um momento filosófico em sala. Sentiu-se tal necessidade, pois o contato inicial com a turma demonstrou um individualismo muito presente. Percebia-se que raramente os alunos faziam atividades que envolvem interação comunitária e em círculo. As carteiras sempre posicionadas em fileiras, os alunos distribuidos de forma fixa nas carteiras. Constantemente a professora gritava com eles para que pudessem escutar ou ir para seus lugares. A turma apresentou muitas dificuldades para a realização de qualquer atividade em grupo. Diante de tal contexto, achou-se indispensável o trabalho de atividades comunitárias que abordassem: a formação do círculo, diálogo entre os participantes, a importância da individualidade na coletividade, o entendimento da relação parte-todo no grupo, a apresentação de razões e exemplos, a elaboração de sínteses e regras, e o trabalho democrático. Para este processo, foram feitas duas atividades: a primeira consistiu na formação de uma teia coletiva utilizando um rolo de barbante, onde os alunos verificaram a importância de um trabalho comunitário evitando que a rede não se rompesse, e a segunda foi uma dinâmica de apresentação de um bichinho de pelúcia (coruja) e uma votação para a escolha do nome deste bichinho que passou a ser o mascote da turma, ou mascote da fala na comunidade. Ele teve a função de ajudar na organização da fala, de maneira que quem quisesse 
falar deveria aguardar a vez até que o outro colega terminasse e lhe passasse o mascote. Enfim, pode-se dizer que o período introdutório foi essencial para a organização das aulas seguintes e para que as crianças fossem criando hábitos de respeito na experiência de comunidade.

A "amizade" foi o conceito escolhido para a abertura da experiência de Comunidade de Investigação. Trata-se de um conceito muito presente na experiência da criança e, ao mesmo tempo, permite ligar o conceito à própria filosofia como a amizade à sabedoria. Por ser a atividade inicial em comunidade investigativa, foram trabalhadas definições breves como palavras do campo conceitual da amizade, com o fim de elaborar, posteriormente, uma definição por meio de frases. Para isso, as crianças definiram a amizade da seguinte forma: “ amizade pra mim é amor", "amizade pra mim significa confiança", "amizade é brincar", "amizade é ajudar" etc. Com as palavras das crianças e mediadores foi construído um mural em forma de girassol. Com isso, procurou-se demonstrar que o significado de uma palavra depende de várias outras, as quais agrupadas com sentido formam uma definição.

Também foi tratado outro tema fundamental ao filosofar dentro deste conceito, que é a pergunta, mediante textos, imagens e objetos a fim de que as crianças pudessem aguçar essa habilidade essencial que é o questionar. As questões “o que é uma pergunta?" e "para que serve?" foram apresentadas. As crianças expunham suas reflexões, as quais foram majoritariamente expressas por exemplos e não definições como: “Uma coisa que se faz, tipo...você é meu amigo?" "gesto bem legal", "quando a gente não sabe das coisas.", " Ela serve para falar, para tirar dúvidas, para contar para um amigo, para perguntar alguma coisa".

Em continuidade foi feita a oficina do perguntar: as crianças foram incentivadas a fazer perguntas com os seguintes pronomes interrogativos: "Quem? Onde? Quando? Qual? Quanto? e Como?". Para isso, foram levadas diversas imagens divertidas as quais continham os pronomes, para que as crianças pudessem criar suas perguntas. De acordo com as regras da Comunidade de Investigação, elas apresentaram suas indagações, as quais foram registradas. Foi uma experiência interessante para as crianças brincarem com a elaboração 
a experiência de pensar conceitos e o filosofar na infância na perspectiva de matthew lipman

perguntas de diferentes formas para a exploração de um conceito. A atividade foi uma provocação para as crinças elaborarem perguntas sobre os assuntos de seu interesse para discussão. As perguntas das crianças foram organizadas em grupos conforme os conceitos que foram programados para serem trabalhados nas aulas seguintes: pessoa, história, nome, criatividade. Desta forma, a agenda de assuntos foi elaborada a partir do interesse dos estudantes.

\section{resultados e observações}

Após a realização do projeto, foi feita uma revisão de toda a experiência, a fim de estabelecer uma associação entre a pesquisa sobre as concepções de Lipman acerca de Filosofia para Crianças e a atividade empírica na escola.

Como primeiro ponto a destacar, em relação ao campo de pesquisa, foi identificada uma incongruência teórico-prática da escola, por afirmar seguir uma perspectiva teórica em seu Projeto Político Pedagógico diferente da realizada em seu cotidiano. Em seu PPP, a instituição afirmava contemplar a aprendizagem como um processo histórico e social, levando em conta a realidade e os conhecimentos prévios dos alunos, porém suas ações refletiam o oposto: as interações entre docentes e discentes aconteciam majoritariamente por comandos da professora e suas atividades não eram ligadas com a realidade deles, tampouco com os interesses dos alunos, uma vez que a docente seguia o unicamente o livro didático.

Mediante as observações e intervenções pôde-se perceber um tradicionalismo muito presente em práticas de leitura do texto do material didático, exercícios e provas. A disposição das carteiras em sala de aula seguia o formato de fileiras em que cada estudante tinha um lugar fixo predeterminado pela professora. O controle dos estudantes era feito por meio de regras e severas chamadas de atenção para quem não seguia as normas. $\mathrm{O}$ hino nacional era tocado no início das atividades, cantado em tom muito fora do alcançe da voz das crianças que se esforçavam para tentar acompanhar. Por outro lado, soava como obrigação rotineira, sem empatia ou entendimento por parte dos estudantes. A docente se mostrava como detentora do conhecimento, consequentemente, notava-se pouca expressividade por parte dos alunos. Além disso, foi identificado um grande apreço 
por instrumentos avaliativos quantitativos como o da prova, que numa ocasião foi marcada para o dia do projeto. Tal fato quase inviabilizou a experiência diante da pressão dos alunos e da professora, pois a prova foi colocada como prioritária. Podese dizer que tais posturas identificadas foram fatores que dificultaram a experiência em geral.

Após o projeto, observou-se um espanto e interesse pela metodologia empregada em sala de aula, e o pedido de uma presença filosófica maior na escola, especialmente a continuidade do projeto.

Em relação aos alunos, notaram-se vários progressos no decorrer da pesquisa. Antes das intervenções, os alunos apresentavam várias dificuldades como já relatadas. A principal identificada foi em relação à convivência: as crianças não sabiam ouvir uns aos outros, falar e fazer atividades com seus colegas como duplas ou grupos. A dificuldade se tornava maior quando era visada interação entre meninos e meninas. Com o avançar das atividades, as crianças começaram a participar mais das atividades que envolviam interação de uns com os outros, demonstrando menos medo e mais reciprocidade, além de um senso de respeito e pertencimento a um grupo.

Do ponto de vista da discussão, as crianças apresentavam uma conceituação muito básica, pois quando queriam definir algo, citavam exemplos ou palavras sem estabelecer razões para isso. Tal aspecto era parcialmente compreensível, pois elas ainda estavam em processo de aquisição da linguagem. Por outro lado, revelaram pouca apropriação de conteúdos relacionados com outras áreas, que faziam parte do trabalho, como é o caso do conceito de "história". Como este conceito está relacionado tanto à disciplina de história, quanto no trabalho com literatura em que se utiliza história de "faz-de-conta" esperava-se que as crianças pudessem apresentar significados relevantes. Isso nos fez refletir sobre uma possível dificuldade de fazer associações, resultante de um ensino atomístico de conceitos.

Outro ponto complicador está no fato das crianças não conseguirem fazer muitas relações entre a temática abordada e as atividades ou recursos trabalhados, fator que dificultava a leitura, realização de perguntas intencionais e síntese do trabalhado. Neste caso, foi possível perceber que a criança está habituada ao 
a experiência de pensar conceitos e o filosofar na infância na perspectiva de matthew lipman

trabalho fragmentado e restrito a texto e exercício de pergunta e resposta fechadas do livro didático, e não numa reflexão que envolve processo com diferentes recursos. Parecia impossível que uma pergunta pudesse ser respondida com diferentes alternativas como no caso dos conceitos trabalhados.

Com as práticas desenvolvidas pôde-se identificar mudanças significativas. Em relação à convivência, as crianças conseguiram se envolver na experiência de Comunidade de Investigação criando e repensando suas regras, pensando nas atitudes do trabalho cooperativo, e que para isso é preciso saber o tempo adequado para ouvir e falar com seus companheiros. Um exemplo disso, foram algumas citações das crianças sobre seus comportamentos e o dos companheiros de classe: "só pode falar quem levantar a mão", "fala sobre a pergunta", "é bom ouvir quando alguém fala" "professora passa a corujinha" (mascote da fala) ou "professora fala: "quem concorda ou não concorda?" Entenderam que era necessário respeitar a fala de cada um e refletir sobre suas opiniões. Quanto à conceituação, deixaram aos poucos de dar exemplos e começaram a formar frases para explicar algum conceito, ou seja, construir definições. No decorrer das aulas, os alunos foram entendendo a metodologia empregada e dando fluidez às discussões, ou seja, necessitando de menos incentivos ou orientações para que se estabelecesse um diálogo, surgindo perguntas para continuidade do processo, que pode ser exemplificado com a questão: "O que é personalidade?" durante o trabalho com o conceito de pessoa. Gradualmente suas perguntas passaram a ser mais focadas nos conceitos trabalhados. Além disso, apresentavam entusiasmo e expectativa nas aulas, aspecto ressaltado inclusive pela avó de uma aluna em conversa informal na recepção da escola, pois eles sabiam que algo diferente lhes esperava. Enfim, entenderam as aulas como momentos em que podiam "exercitar a mente", expressão usada pelas crianças, e se divertir ao mesmo tempo.

Em relação ao trabalho docente, como organizadores e participantes do projeto, pode-se dizer, que obtivemos oportunidades e aprendizagens únicas. Apesar da experiência se restringir a um semestre letivo, pôde-se realizar a exemplificação da formação docente sugerida por Lipman na prática de uma Comunidade de Investigação, conceito central na formação de docentes que 
pretendem trabalhar a filosofia na infância. Com a pesquisa, foi possível o planejamento em conjunto com professor orientador e o acompanhamento das práticas de avaliação de cada encontro, tanto dos aspectos teóricos quanto da realidade da turma e da escola. Ademais, foi oportunizada uma identificação e mudança das práticas tradicionais ainda enraizadas no fazer docente como estudante na prática na escola, as quais foram destacadas nos diários de campo. Além disso, foi possível experienciar a criação de planejamentos e de materiais de acordo com a proposta, elementos que sem dúvidas foram enriquecedores para a formação pedagógica.

Por último, destaca-se que apesar dos avanços conquistados, é preciso o desenvolvimento de um trabalho contínuo e rigoroso a fim de que os conhecimentos socializados em Comunidade de Investigação sejam internalizados e melhor compreendidos pelas instituições, alunos e docentes.

\section{considerações finais}

Com a presente pesquisa foi possível perceber a contribuição essencial da filosofia em relação à formação de conceitos na infância. $\mathrm{O}$ aspecto da curiosidade, indagação e investigação, característicos da filosofia, se assemelha ao comportamento das crianças, e constitui uma propulsão do pensamento crítico e criativo, e cuidadoso. Diferentemente de outros campos do conhecimento, a filosofia tem como objeto trabalho de criticidade e criação de conceitos, convertendo-se em disciplina por excelência da análise e desenvolvimento dos significados e transformação da experiência. Por ser uma área de conceitos abertos, possibilita a investigação sem renunciar à rigorosidade e à razoabilidade. Associada à educação, a filosofia pode proporcionar uma experiência de liberdade de pensamento que amplia a forma relativamente rígida das ciências e de certas abordagens moralistas. Graças a ela e à metodologia da Comunidade de Investigação apresentada por Matthew Lipman, com seu trabalho de habilidades cognitivas e busca da excelência do pensar, os alunos sentem-se sujeitos de seu processo de aprendizagem, seguros para compartilhar seus conhecimentos e motivados a ampliar sua razão e principalmente sua maneira de conceituar. Pode- 
a experiência de pensar conceitos e o filosofar na infância na perspectiva de matthew lipman

se verificar que tal prática é possível de ser realizada em sala de aula.

Destacamos que o estudo permitiu perceber a importância fundamental da experiência, segundo Lipman, na formação de docentes iniciantes em Filosofia para Crianças. A prática do diálogo conceitual se torna efetivo na formação de professores, além disso, provê aprendizagens que só são possíveis com experiência discente. Espera-se que com este trabalho os olhares das escolas e dos professores se ampliem em relação à filosofia e alguns preconceitos possam ser repensados. Quanto à educação reflexiva, e principalmente a concepção de Filosofia para Crianças, há muito a ser feito ainda. Consequentemente, como fator principal observa-se a necessidade da ampliação da formação docente em filosofia da educação e filosofia da infância e uma conscientização em todos os âmbitos da nossa sociedade dessa importância. Com isso, espera-se uma prática mais dialógica e ética entre docentes e estudantes. Destaca-se a importância desta prática para o exercício democrático desde a infância.

\section{referências}

Abbagnano, Nicola. Dicionário de filosofia. 5.ed. São Paulo: Martins Fontes, 2007.

Aplicação, Colégio de. O Colégio de Aplicação Pedagógica da UEL disponibiliza para consulta o Projeto Político Pedagógico. Disponível em: <http://www.uel.br/aplicacao/pages/arquivos/PPP2016.pdf>. Acesso em: 17 mai. 2018.

Araujo, Ulisses F. A educação e a construção da cidadania: Eixos temáticos da ética e da democracia. In: MEC. Ética e Cidadania: construindo valores na escola e na sociedade. Brasília: Ministério da Educação, 2007. p. 11-21.

Bakhtin, Mikhail. Marxismo e Filosofia da Linguagem. São Paulo: Editora Hucitec, 1997.

Claparède, Édouard. A educação funcional. Trad. J.B. Damasco Penna, 5a. ed., São Paulo: Nacional, 1958.

Colenghi Filho, Maurício; Velasco, Patrícia Del Nero. A argumentação e o ensino dialógico da Filosofia. EIDEA-Revista Eletrônica de Estudos Integrados em Discurso e Argumentação, Ilhéus, n.18, p. 90-103, abr. 2019.

Daniel, Marie-France. A filosofia e as crianças. Trad. Luciano Vieira Machado. São Paulo: Nova Alexandria, 2000.

De Freitas Zompero, Andréia; Sampaio Figueiredo, Helenara R.; Laburú, Carlos Eduardo. Estudo das habilidades cognitivas de alunos da educação básica em atividade sobre verminoses. Enseñanza de las ciencias, n. Extra, p. 4259-4264, set. 2017.

Dewey, John. Como pensamos como se relaciona o pensamento reflexivo com o processo educativo: uma reexposição. Tradução: Haydée Camargo Campos. $4^{\mathrm{a}}$ ed. São Paulo: Nacional, 1979a. Atualidades pedagógicas; vol. 2.

Dewey, John. Democracia e educação. Tradução: Godofredo Rangel e Anísio Teixeira. São Paulo: Nacional, 1979b. Atualidades pedagógicas; vol. 21. 
Dewey, John. Experiência e educação. Tradução: Anísio Teixeira. São Paulo: Editora Nacional, 1976.

Durkheim, Emile. A evolução pedagógica. Porto Alegre: Artes Médicas, 1995.

Eby, Frederick. Herbart e a ciência da Educação. In: Durkheim, Emile. História da Educação moderna; sec. XVI/ sec. XX - teoria, organização e prática educacionais. $5^{\text {a }}$. ed. Porto Alegre: Globo, 1978. p. 408-429.

Favero, Altair Alberto; Centenaro, Junior Bufon; Kapczynski, Ana Lúcia. O ensino de Filosofia como potencializador da experiência interdisciplinar na Educação Básica: interfaces entre Hannah Arendt e Matthew Lipman. Conjectura: filosofia e educação, Caxias do Sul, v. 24, p.57-75, jan. 2019.

Fernandes, João Bosco. Habilidades de pensamento na aula de Filosofia. In: BARATA, A. et al. Filosofia, Comunicação e Subjetividade: Pensamento Crítico, Psicologia e Educação. v. 2. Covilhã: LabCom.IFP, 2018. p.193-211.

Franca, Padre Leonel S. J. O método pedagógico dos Jesuítas. São Paulo: Agir, 1951. (Ratio Studiorum).

Freire, Paulo. Educação como Prática da Liberdade. 19. ed. Rio de Janeiro: Paz e Terra, 1989.

Freire, Paulo. Extensão ou Comunicação? 4. ed. Rio de Janeiro: Paz e Terra, 1980.

Freire, Paulo. Pedagogia do Oprimido. 25. ed. Rio de Janeiro: Paz e Terra, 1998.

Herbart, Johann Friedrich. Pedagogia geral. Trad. Ludwig Scheidl. Lisboa: Fundação Calouste Gulbenkian, 2003.

Japiassu, Hilton; Marcondes; Danilo. Dicionário básico de filosofia. 5. ed. Rio de Janeiro: Zahar, 2008.

Kohan, Walter O.; Waksman, Vera. Filosofia para crianças na prática escolar. 2. ed. Petrópolis: Vozes, 1998.

Köhler, Wolfgang. Psicologia da Gestalt. Belo Horizonte: Itatiaia.1980.

Konder, Leandro. O futuro da filosofia da práxis: o pensamento de Marx no século XXI. Rio de Janeiro: Paz e Terra, 1992.

Leontiev, A. Sobre o desenvolvimento histórico da consciência. In: Leontiev, A. O desenvolvimento do psiquismo. Lisboa: Horizonte Universitario. 1798. p. 89-142.

Lipman, Matthew. Philosophy for children. Metaphilosophy, [S. 1.]. v. 7, n. 1, p. 17-39, 1976.

Lipman, Matthew. A filosofia vai à escola. 2. ed. São Paulo: Summus, 1990.

Lipman, Matthew. O pensar na educação. Petrópolis: Vozes, 1995.

Lipman, Matthew. Pimpa. Tradução de Sylvia Judith H. Mandel, 2. ed. São Paulo: Difusão de Educação e Cultura, 1997.

Lipman, Matthew. Prefácio. In: Daniel, Marie-France. A filosofia e as crianças. Trad. Luciano Vieira Machado. São Paulo: Nova Alexandria, 2000.

Lipman, Matthew. Thinking in education. Cambridge: Cambridge University Press, 2003.

Lipman, Matthew. Filosofia na sala de aula. Matthew Lipman, Ann Margaret Sharp, Frederick S. Oscanyan; Tradução Ana Luiza Fernandes Falcone. 2. ed. São Paulo: Editora Nova Alexandria, 2014.

Lipman, M.; Oscanyan, F.; Sharp, A. M. Filosofia na sala de aula. São Paulo: Nova Alexandria, 1994.

Lorieri, Marcos Antônio. Filosofia no Ensino Fundamental. São Paulo: Cortez, 2002.

Madaloz, Marcos Antônio Martinelli. A atualidade da proposta educação para o pensar de Matthew Lipman diante das políticas para o ensino de Filosofia. 2018. Dissertação (Mestrado em Educação) - Universidade de Passo Fundo, Passo Fundo, 2018.

Magoga, Patrícia Melo; Muraro, Darcísio Natal. A escola pública e a sociedade democrática: a contribuição de Anísio Teixeira. Educação \& Sociedade, Campinas, v. 41, e236819, set. $2020 . \quad$ Disponível em: <http:/ / www.scielo.br/scielo.php?script=sci_arttext\&pid=S0101733020200001003 27\& ng=en\&nrm=iso>. Acesso em: 09 nov. 2020. 
a experiência de pensar conceitos e o filosofar na infância na perspectiva de matthew lipman

Matthews, Gareth B. A filosofia e a criança. São Paulo, Martins Fontes, 2001.

Mazzotti, Tarso Bonilha. Filosofia da Educação, uma outra filosofia? In: Ghiraldelli, Paulo. O que é Filosofia da Educação? Rio de Janeiro: DP\&A, 1999. p.187-206.

Mead, G. H. The psychology of social consciousness implied in Instruction. Disponível em <https://www.ncbi.nlm.nih.gov/m/pubmed/17754745/>. Acesso em: 17 mai. 2018.

Muraro, Darcísio Natal. A educação Filosófica: Fundamentos e Metodologia. Curitiba: IFEP, 2015.

Prado, M.S.M. Psicologia da Educação. Cruz das Almas: SEAD-UFRB, 2017.

Reale, Miguel. Estudos avançados. Disponível em:<http://www.scielo.br/scielo.php?script=sci_arttext\&pid=S0103

$40141991000300008 \& \operatorname{lng}=$ en\&nrm=iso>. Acesso em: 22 abr. 2019.

Saviani, D. Escola e democracia. 24. ed. São Paulo: Cortez, 1991.

Severino, Antônio Joaquim. A busca do sentido da formação humana: tarefa da Filosofia da Educação. Educação e Pesquisa, São Paulo, v.32, n.3, p. 619- 634, set./dez. 2006

Scheler, Max. Visão filosófica do mundo. São Paulo, Editora Perspectiva, 1986.

Splitter, Laurance J.; SHARP, Ann Margaret. Uma nova educação: a comunidade de investigação na sala de aula. São Paulo: Nova Alexandria, 1999.

Teixeira, Anísio. Educação no Brasil. 2. ed. São Paulo: Companhia Editora Nacional, 1969.

Teixeira, Anísio. Educação não é privilégio. 3. ed. São Paulo: Companhia Editora Nacional, 1971.

Teixeira, Anísio. Educação é um direito. 4. ed. Rio de Janeiro: Editora UFRJ. 2009.

Teixeira, Anísio. Pequena Introdução à Filosofia da Educação. Escola progressiva ou a transformação da escola. 6. ed. Rio de Janeiro: DP\&A, 2000.

Vale, Jocilaine Moreira Batista do. O ensino da filosofia na educação básica: Uma experiência no município de Pacatuba a partir da perspectiva de Matthew Lipman. 2019. Dissertação (Mestrado em Filosofia) - Universidade Federal do Ceará, Fortaleza, 2019.

Vygotsky, L. S. A formação social da mente. São Paulo: Martins Fontes, 1994.

Vygotsky, L.S. Aprendizagem e desenvolvimento intelectual na idade escolar. In: Vygotsky, L. S., Luria, A. R., Leontiev, A. N. Linguagem, desenvolvimento e aprendizagem. 5. ed. São Paulo: Ícone, p. 103-117, 1998.

recebido em: 2020.08.11

aprovado em: 2020.11 .09 